\title{
Develop of Strategic Position in Private Clubs Through Leverage and Brand Reputation
}

\author{
Rasool Nazari* \\ Assistant Professor, Islamic Azad University, Isfahan, Iran \\ Submission: March 19, 2019; Published: April 01, 2019 \\ *Corresponding author: Rasool Nazari, Assistant Professor, Islamic Azad University, Isfahan, Iran
}

\begin{abstract}
The purpose of this study was developed of strategic position in private clubs through leverage and brand reputation. The method of this descriptive study was causal, which was conducted by survey method. The statistical population of this study was based on the statistics provided by the Office of Clubs of the Sports and Youth Department of Isfahan Province. Regarding the uncertainty of the statistical community, the statistical sample was considered to be 384 for quantitative research. Sampling method in this research, stratified random sampling Isfahan city districts. The instrument of measurement in this research was standard questionnaire. These questionnaires, which were set up based on the research objectives. used Cronbach's alpha coefficient, the reliability coefficient of the brand leverage questionnaire was 0.75 , brand reputation was 0.79 and promotion of brand strategic position was 0.75 . To analyze the findings of this research, structural equations were used. The results of the research showed that the estimated value of brand leverage influence on brand reputation and promotion of brand strategic position of private clubs was 0.34 and 0.91 , respectively. Estimated impact of brand reputation on promotion of strategic position of private club was 0.43 , respectively. Therefore, it can be admitted that it is better for club managers to introduce a special value in terms of their clubs' ability to promote and promote their brand.
\end{abstract}

Keywords: Brand Leverage; Brand Reputation; Strategic; Private Clubs

\section{Introduction}

Brand strategic management is a suitable strategy for fulfilling stakeholder expectations, so that some of its neglect will cause irreparable burns Kennlley \& Toohey [1]. Brand in a highly competitive marketplace today is one of the biggest challenges for any business, so the brand has a strategic value and can be an important part of intangible assets in an organization Bodet \& Chanavat [2]. Considering the quality of services and perceived value affect brand equity, brand equity also has an impact on brand preferences and intent to buy customers Ebrahimi [3]. Thus, it seems that building a strong brand in the market is the goal of many organizations, so experts believe that a brand can create value more than common value. Today, brand is not just an efficient tool in the hands of managers, but a brand is a strategic requirement that helps organizations create value for customers and also create sustainable competitive advantage Keller [4]. Hence, the formation and management of a brand is currently a common marketing strategy for brands aimed at increasing consumer commitments and financial performance Sharifi [5]. In line with the importance of strategic thinking in the brand-building Nazari \& Ghavami [6], the impact of brand credibility on the brand's strategic position has been indirectly emphasized through brand unity.

Nazari \& Haddadi [7] indicated that quality of service affects customers' satisfaction and loyalty and promotion of brand strategic position. From a strategic point of view, brand commitment and brand image have the most impact on brand image and the components of brand judgment and the least impact on brand equity has been considered by the customers Nazari \& Mokhtari [8]. Bijnaci [9] points out that the brand image will have a significant impact on brand equity appreciation from the perspective of customers, Therefore, after carefully analyzing stakeholder needs, brand identity should be considered, and after developing a brand-driven strategy, take steps to implement the strategies and enhance the company's performance in meeting the expectations of the stakeholders Kennlley \& Toohey [1]. Therefore, it can be admitted that brand is the most important thing that most marketing strategies focus on and highlight it. Therefore, brand is one of the most important assets of any organization Nazari \& Ghavami [6].

Branding in a highly competitive marketplace today is one of the biggest challenges for any business, and given the sensitivity of the sports clubs, the brand is at the forefront of strategic value because the brand can be an important part of assets the intangible of sports organizations Bodet \& Chanavat [2]. The importance of the role of intangible assets in the effectiveness of the organization's activities, as well as the creation and survival of financial performance of businesses at the level of organizations, companies and various industries is obvious to everyone. Intangible assets are long and unobtrusive assets that are 
developed and expanded by an organization and are considered as assets of the company. Hence, it can be admitted that brands more than all assets are valuable and add to the economic and strategic value of their owners Raasuli [10]. In the field of sport, the value of a brand, if used correctly, can bring very high profits for the sports club Jalayee [11]. One of the important tools for brand development is leverage. In leverage strategies, managers with the lowest resources are looking for the most results. As leading brands always seek out the results so that they can keep their customers in mind for their products and services. In this regard, brand leverage with good products and services plays an important role in the organization's display. Hence, brands are seeking such strategies for goods or services Sudaryanto [12]. Important factors in brand leverage are the values that provide products and services to our customers. Values that meet the real needs of customers in a quality manner Sobodh \& Srinivas [13].

Brand reputation is more meaningful than keeping customers happy and reflects the achievement that the company gains over time and refers to how different audiences evaluate the brand. Consumers expect the brand to fulfill their demands; demands made by brand reputation Veloutsou \& Moutinho [14]. Today, sport is a phenomenon that, in the event of optimal exploitation of it, can be achieved in many categories, including economic, cultural, and social Abbaspour Tehrani Fard Ahmadi [15]. The sports industry plays an important role in the development of the economy in developed countries Jalayee [11] and direct economic impact on the production of goods and services of sports, employment, exports and imports, the creation of places and facilities, employment, tourism attraction and sponsors and indirect effects on the promotion of community health Ghaderi [16]. Investing in the production of sports products and sports services adds to employment creation on GDP, which will boost economic growth and social prosperity Sharifian [17].

The clubs are depicted as social and economic organizations and they produce goods and services. Private clubs contribute to social cohesion and economic partnerships through direct income, such as: job creation and indirect: the marginal costs of supporters Ebrahimi [3]. In such a situation, managers are more successful in prioritizing the economic aspect of sport Azadi [18]. Branding is an intrusion strategy for sports organizations both at the domestic and international levels and one of its most important assets Keller [19]. Sports organizations such as clubs can use their marketing to focus their customers on recognizing and reinforcing the personality dimensions of the club, and they will strengthen brand and create value for the club's brand. Branding can increase the likelihood of choosing a brand and brand among different brands, the desire to pay special costs, the effectiveness of marketing communications and the increasing popularity among fans and the community Khandan [20].

In the first step at this stage, the creation of brand identity is firmly established and constantly in the minds of the consumer, and then the preference and loyalty of the commitment to the brand are created Sharifian [16]. Therefore, managers can use branding strategies. For example, leverage brand credibility through social responsibility, customer satisfaction, and quality of service for customers Filo \& Funk [21]. Use of the brand as a confirmatory role for consumer confidence, especially goods and services, creates leverage and synergy for achieving goals Sudaryanto [11]. Sport clubs should always seek to promote brand equity. This is the first to attract new customers and, moreover, to serve as a reminder for current customers Bahrain Zadeh \& Ziaee [22]. Sport has played a role in the past decades and is increasingly affecting macroeconomic investment. With the theme of the sport economy, sports and economic players are seeking to grow their income sources in sport in order to grow their complex. In view of the progress, development and popular appeal of people to sport on the one hand and the availability of suitable and high capacities in this sector, on the other hand, it requires accurate knowledge of the status quo and the provision of a basic and scientific strategy for determining the strategy of private clubs in the horizon of the medium term and Short-term is essential.

As a whole, the goal of private clubs from strategy is to create an appropriate platform to enhance the quality of service and customer loyalty. It seems that the brand is not so specific to private clubs, and not only as an intangible asset, but also as an asset for which no definite value has been defined. Probably the achievements of the present research model will determine the factors affecting the brand's strategic position. The significance of the present research reveals that addressing the brand equity issue, which is one of the main assets of the club, can be of great importance. It is worth noting that most clubs today are trying to be introduced as a superior brand, which, on the one hand, attracts and retains loyal customers and, on the other hand, leads to the achievement of the desired economic goals. Given the growing importance of customers to gaining benefits for organizations, the concept of loyalty of customers today is one of the factors that has attracted the attention of organizations. Since the impact of brand leverage (such as trust, commitment, satisfaction, and service quality) on brand reputation and strategic position of the club can play a decisive role in the success of the club. The ability to maintain customers through brand loyalty and reduce marketing costs has an important role. Despite the emphasis on the importance of customers in the service sector, measuring the value of brands and considering its cognitive aspects is almost a new position in the concept of service marketing in comparison with product marketing, which should be considered more. Therefore, considering the above mentioned and studies, the researcher seeks to answer the question of whether the brand effect of branding and brand reputation on promoting the strategic position of private clubs is fit for?

\section{Methodology}

The current research is applied in terms of its purpose and in terms of correlation method. Surveying information collection 
method. In this research, the brand's leverage researcher (science, awareness and experience), brand reputation (background, claims, and customers) and promotion of brand strategic position (trust and loyalty, quality and quantity of services, social and communication approach, reputation and advertising, and price) In the same way and without interference, from the perspective of private club customers. Based on the inquiry from the Office of Clubs of the Sports and Youth Department of Isfahan Province, the number of private club clients is not known, so the sample size was considered 384. The measurement tool consists of a questionnaire for brand leveraging, a researcher made and consists of 10 questions and 2 dimensions. The questions in this questionnaire relate to the components of knowledge, knowledge and experience, each of which is calculated separately. Taliban brand reputation questionnaire (2012) includes the dimensions of history, claims and customers. The questionnaire for promotion of strategic brand equity (2009) includes elements of trust and loyalty, quality and quantity of services, social and communication approach, reputation and advertising and price. To determine the reliability of the questionnaire, they were experts in sport management and experts in the field of strategic and marketing and confirmed the validity of the questionnaires. For reliability of the researcher's questionnaire, firstly, 30 simple questionnaires were randomly distributed in the population under study and collected after completing. By calculating the variance of this sample, based on the Cronbach's alpha coefficient, the reliability of brand leverage questionnaire was 0.75 , brand reputation $79 / 0$ and the promotion of brand strategic position is 0.75 . To analyze the research data at the level of inferential statistics, to test the hypotheses of the research, we first use the Kolmogorov-Smirnov test to ensure the distribution of the sample is normal and the Levine test is used to ensure homogeneity of variance. After establishing these preconditions, a structural equation modeling test was used to represent the model to compare the mean of the sample with the hypothetical mean of society. Statistical methods were performed using SPSS software version 22 and Amos software at error level of 0.05 .

\section{Findings}

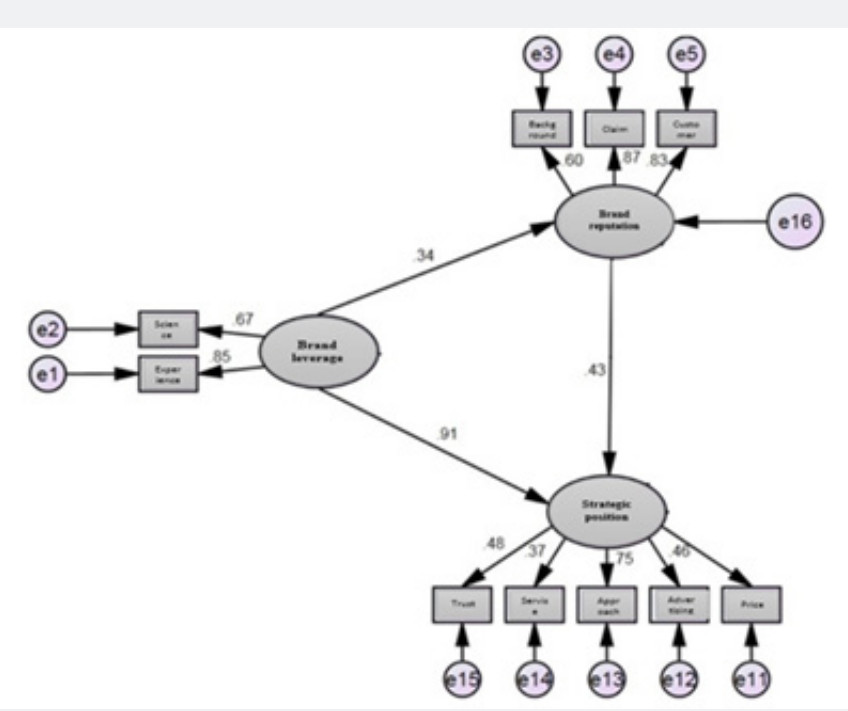

Figure 1: The Main Model of Research.

Table 1: Major Indicators of Modeling Fit.

\begin{tabular}{|c|c|c|c|}
\hline \multicolumn{4}{|c|}{ General indexes of model fit } \\
\hline $\begin{array}{c}\text { Number of estimated } \\
\text { parameters }\end{array}$ & P- Value & Chi/df & RMSEA \\
\hline 5 & 0.386 & 1.23 & 0.04 \\
\hline
\end{tabular}

The gender of the subjects studied in this research is shown. Accordingly, about $74 \%$ of the subjects are women and about $26 \%$ of men. Six percent of the subjects were people aged 20 to 26 years old, 52 percent in the age group of 27 to 35 , and 32 percent at age 36-44 and 10 percent at the age of 45 and above. Among the research variables, brand reputation variable with average of 3.78 has the highest average and the promotion of brand strategic position with average of 3.28 has the lowest average. To assess the adequacy of the model, the main focus is on the general fitting indices of the model. p-value of the model is $<0 / 05$ and RMSEA $>050 / 0$. So, the proposed model is appropriate (Figure 1) \& (Table 1).

\section{Discussion and Conclusion}

Considering the high average of all variables of research is higher than the average level, the implementation of measuring models on the effect of brand leverage on brand reputation and promotion of the brand strategic position of private clubs indicates high fit and confirmation of the conceptual model of research. Therefore, it is suggested that club managers consider the approach of providing services in line with the interests and wishes of customers in order to promote the brand's position in the competitive market. The results of this study are partly consistent with the results of the Nazari \& Haddadi research [6], the effect of quality of service on customer satisfaction and loyalty and promotion of the strategic position of the 
private club brand. Perhaps the reason for this alignment of the statistical society is the same as in both research uses Has been. The results of the study showed that the estimation of the impact of brand leverage on brand reputation of private clubs is affected. The results of this study are partly consistent with the achievements of Huang \& Sarigollu [23] as the analysis of awareness of the factors affecting brand development through brand equity, combined marketing and market outcomes. Their results showed that a well-known brand is more likely to be chosen by customers than an anonymous brand. The wellknown brand has a better performance in gaining market share than a less well-known brand. It can be said that the model at the pre-introduction stage consists of a series of activities, so that a brand can enter the market when it comes to the market. This is the key to brand management, so it's very important. In the second phase, as the competition is on the rise, brand equity is important. For example, imitation of brands has made it difficult for customers to make distinctions. In addition, increasing customer awareness makes this issue even more critical. In the third stage, the goal is to create and strengthen the brand. To this end, if the products manufactured by the company are placed in different categories, different products that are similar to each other will enhance each other's worth. Products that have similar brands can be intriguing to the customer, which should be consumed, and this is very good when the brand is entering the market, as shown below. In explaining these results, it can be argued that commercial brands, especially those with high value, can be considered as the most powerful assets of the organization. This allows organizations to benefit from highlevel brand loyalty, brand awareness, perceived quality, and strong linkage with the customer [24].

The results of the research showed that brand leverage has an impact on the promotion of the strategic position of the private club brand. The results of this study are partly consistent with the model of the Clare brand strategy management process (2010). In this model, the model considers the process of strategic management in four stages: identifying and creating a brand position, designing and implementing brand marketing programs, measuring and analyzing brand efficiency, brand growth and sustainability. In explaining these results, it can be argued that the leverage of the brand and the image of the company during different periods of time is such that they occupy a significant amount of the mind of the target audience group. So that the potential benefits of the business are at its highest. Brand positioning is very important in order to convince consumers of the benefits or points of difference that the brand has over competitors.

The results of the research showed that brand reputation affects the promotion of the strategic position of private clubs. The results of this research are partly consistent with the results of the current research and Qavami Komala [5], the effect of brand credibility on Brand Alliance strategy to promote the brand's strategic position: A case study of Sepahan Club of Isfahan. The results of their research showed that the effect of brand credibility on the strategic position of the brand was indirectly through brand unity. The results of implementing the models of measuring the effect of brand credibility on brand strategy strategies, the effect of brand credibility on promotion of brand strategic position, and the strategy of unity on the strategic position of brand represent the high fit of the model and confirm the conceptual models of research. In explaining these results, it can be said that in order to increase brand reputation and promote the strategic position of private clubs it is desirable to awareness and conceptualization, search and development of the program, promotion and promotion of brand, management and brand control, and finally, the result of attention to be placed. Therefore, they suggested that club managers consider the approach of providing services in line with the interests and wishes of customers in order to promote the brand's position in a competitive market. In explaining these results, it can be said that the brand should be looked at as an asset so that in the first stage, brand image is created; in the second stage, it is to be understood the brand's concept and brand; in the third stage, it is a brand strategy. Which should be tailored to the needs of customers and the organization's goals, and the vital features of the product in order to properly understand the customers of the organization and its products. The final step is to measure the return on the value of the brand.

Private brand leverage with elements of knowledge and knowledge and club brand building experiences as a predictor variable, as well as brand reputation variables with historical components, claims, and number of customers alongside the variable of strategic brand equity of private clubs as a criterion variable in The present study considered that the components of trust, quality, approach, reputation and price were considered as components of promoting the strategic position of private clubs. In general, it can be admitted that private club executives try to raise and improve the trust and quality and innovation of their brand products and services, which increases with the brand credibility of the customer club, which makes customers use the service and recommend the products of the club to others. Brand marketing executives who are at the top of the brand's alliance can help to make a positive assessment of brand credibility through branding by selecting a brand of high-reputable partner. Hence, considering the results of the research on the role of the quality of service, the managers of the private clubs always have the quality cycle in motion. Private club managers will place more emphasis on the club's brand and will care about the interests and aspirations of athletes. Therefore, it's better for clubs to provide their services in line with the interests and wishes of their customers. Club managers consider Brand as the most powerful club property. Managing factors to leverage their own will attract a significant amount of the mind of the target audience group. 


\section{References}

1. Kennelly M, Toohey K (2014) Strategic alliances in sport tourism: National sport organizations and sport tour operators. Sport Management Review 17(4): 407-418.

2. Bodet G, Chanavat N (2010) Building global football brand equitylessons from the Chinese market. Journal of Marketing and Logistics (22)1: 8-24.

3. Ebrahimi A, Alavi M, Siahroodi M (2014) The effect of their benefits on customer satisfaction and behavioral loyalty to the brand (Case Study: Brand Staples). Journal of Management Science 9(35): 95-113.

4. Keller K (2001) Building Customer-Based brand equity. Marketing Management 12(2): 14-19.

5. Shafaeii L, Memari J, Asghari Jafar Abadi M (2018) The brand personality of the selected football teams of the Iranian Football League defines dimensions and presents a route model. Journal of Management and Sports Development 5(1).

6. Nazari R, Qavami Komala F (2018) The Effect of Brand Credit on Brand Branding Strategy to Promote Brand Strategic Position: Case Study of Sepahan Club of Isfahan. Applied Research in Sport Management 6(1): 71-61.

7. Nazari R, Haddadi S (2018) The Effect of Quality of Services on Customer Satisfaction and Loyalty and Promoting the Strategic Position of Private Club Clubs: Providing Model. New Approaches to Sport Management 5(17): 56-45.

8. Nazari R, Mokhtari M (2019) Presentation of the brand elements of the brand of professional football clubs based on the brand value of the customers. Management and development of sports 7(4): 71-80.

9. Bijunaci, Mohan A (2015) The impact of CBBE on the operational performance of FMCG companies in India. The international Journal of management 1-19.

10. Rasuli M, Khabiri M, Elahi A, Aghaei N (2016) Factors and Challenges of the Brand Manager of the Football Clubs of Iran. Sport Management Studies 35: 66-51.

11. Jalayee SA, Bakhshandeh H, Esmaeili M, Rasoli SM (2017) The Effects of Technology Spillover on the Economic Growth of Iran's Sports Industry.

12. Sudaryanto S (2015) Brand Leverage Strategy throughout Sport Championship and Amusement: The Case of Banyuwangi Festival 2013. ELSEVIER, Procedia - Social and Behavioral Sciences 211: 1171-1178.
13. Sobodh B, Srinivas (2010) The impact of parent brand attribute associations and effect on brand extension evaluation. Journal of business research 53(3): 111-122.

14. Veloutsou C, Moutinho L (2009) Brand relationships through brand reputation and brand tribalism. Journal of Business Research 42(3): 314-355.

15. Abbas Pour Tehrani Fard MH, Ahmadi A (2018) Formulating key criteria for the HSE field affecting the marketing of sports stadiums. Online publication.

16. Ghaderi (2015) Prioritizing the social impacts and sport of the places of sport on the urban environment (Case study of Yazd city) 15.

17. Sharifian E, Yousefi Zarandi MH, Ghahraman Tabrizi K (2015) Barriers to the part of the sports industry in competing with foreign sporting goods. Practical research in sports management 5(1): 73-82.

18. Azadi R, Eidy H, Yousefi B (2015) Study the sources of income for football in the world and compare it with football clubs in Iran (identifying obstacles and providing solutions for it). Magazine Market Engineering Development (TMBA) 1-17.

19. Keller KL (2010) Brand Equity Management in a Multichannel, Multimedia Retail Environment. Journal of Interactive Marketing 24: 58-70.

20. Khandan N, Etiqua N, Mokhtari Dinani M (2019) Brand-specific brand relationship with consumer-brand brand equity in popular football teams selected by the national football league. Applied Research in Sport Management 6(24): 83-91.

21. Filo K, Funk DC (2008) Exploring the role of brand trust in the relationship between brand associations and brand loyalty in sport and fitness. International Journal Sport Management and Marketing 3: 39-54.

22. Bahraini Zadeh M, Ziaee A (2013) Providing a model for identifying and evaluating the effect of sport sponsorship on brand equity and brand equity. Journal of Business Studies 55(1): 239-250.

23. Huang R, Sarigöllü E (2012) How brand awareness relates to market outcome, brand equity, and t marketing mix. Journal of Business Research 65(1): 92-99.

24. Saeedi R, Emad Hosseini, Farzam F (2015) Its quality of service and customer satisfaction and loyalty clubs for women in Mazandaran province. A study sports management and motor behavior 11(22): 2938.

\footnotetext{
Your next submission with Juniper Publishers will reach you the below assets

- Quality Editorial service

- Swift Peer Review

- Reprints availability

- E-prints Service

- Manuscript Podcast for convenient understanding

- Global attainment for your research

- Manuscript accessibility in different formats

( Pdf, E-pub, Full Text, Audio)

- Unceasing customer service

Track the below URL for one-step submission https://juniperpublishers.com/online-submission.php
} 